\title{
La huella de El Escorial en las cúpulas españolas de finales del siglo XVI. El caso de la Capilla Cerralbo de Ciudad Rodrigo
}

\author{
The influence of the Escorial on Spanish domes at \\ the end of the 16th century. The case of Cerralbo Chapel \\ in Ciudad Rodrigo
}

\author{
$\underline{\text { A. López-Mozo }}^{*}$
}

\section{RESUMEN}

El Escorial ejerció una influencia directa en la construcción de cúpulas en España, acrecentada por la publicación en 1589 de las Estampas, dibujos de Juan de Herrera que describían el edificio incluyendo una sección de la cúpula principal. Este trabajo muestra esa influencia en los exponentes más significativos de finales del siglo xvı, descartando paralelismos de estilo y apoyándose en datos documentales. Proyectos iniciales de cimborrios eran sustituidos por cúpulas trasdosadas, se añadían tambores, se tomaban proporciones de la sección escurialense o se copiaba su disposición constructiva. Se ofrece, además, el estudio detallado de una de ellas, la cúpula de la Capilla Cerralbo de Ciudad Rodrigo, trazada inicialmente por Juan de Valencia, ayudante de Juan Bautista de Toledo y Juan de Herrera en El Escorial. La investigación se apoya en levantamientos rigurosos de El Escorial y la Capilla Cerralbo realizados por la autora.

970-9

Palabras clave: Cúpulas; cantería; levantamiento arquitectónico; siglo XVI; Ciudad Rodrigo; El Escorial; Juan de Valencia; Juan del Ribero Rada.

\section{SUMMARY}

The Escorial had a direct influence on dome construction in Spain, increased by publishing the Estampas in 1589, drawings by Juan de Herrera of the building including a cross section of the main dome. This work shows that influence on the most relevant domes at the end of the 16th century, supported by objective data and discarding style similarities: initial projects were varied to include extradosed domes, tambours were added, Escorial's section proportions were taken or its constructive arrangement was copied. A specific study on the dome of the Cerralbo Chapel in Ciudad Rodrigo is also included, as it was initially designed by Juan de Valencia, assistant to Juan Bautista de Toledo and Juan de Herrera at the Escorial. The research is supported by rigorous surveys both of the Escorial and Capilla Cerralbo, carried out by the author.

Keywords: Domes; stonecutting; architectural surveying; 16th century; Ciudad Rodrigo; The Escorial; Juan de Valencia; Juan del Ribero Rada. 
La consolidación en España de la tipología de cúpula renacentista sobre tambor Ilegaría con El Escorial, cuyo crucero se cerraba entre 1579 y 1582 (1, pp. 495 y 505). Podría considerarse como ejemplo anterior la sacristía de la iglesia de San Miguel en Jerez de la Frontera, terminada por Hernán Ruiz el Joven en 1564 (2, p. 172), aunque las generosas dimensiones del tambor en el exterior lo independizan del conjunto.

En una obra de fábrica las tensiones son pequeñas y la estabilidad es un problema de equilibrio, ligado a la geometría: si es posible encontrar una línea de empujes contenida dentro de la fábrica, el edificio será estable (3, pp. 434-435). En el caso de una cúpula sobre tambor, que asume en solitario la responsabilidad de absorber empujes al no existir contrarresto de bóvedas colindantes, el proyecto de la sección es clave. Considerando que el diseño estructural tenía todavía en el siglo xvı un fundamento empírico, por repetición de reglas extraídas de modelos reales, la inexistencia de ejemplos anteriores en España debió de convertir en un reto la construcción de las primeras cúpulas sobre tambor. La documentación gráfica disponible sería inicialmente sólo la difundida por los tratadistas clásicos sobre modelos de la Antigüedad y el Renacimiento, que tendría valor no sólo como reflejo de modelos arquitectónicos a emular, sino como pautas de diseño estructural.

La influencia de la cúpula de El Escorial se vería acrecentada por la publicación en 1589 de las Estampas, dibujos de Juan de Herrera del monasterio grabados por P. Perret, incluyendo una sección de la cúpula. Las Estampas presentan cambios importantes respecto a lo construido, a pesar de que el edificio estaba ya terminado: en la cúpula muestran un tambor y una linterna más altos y una calota más gruesa (4, pp. 457458; 5, pp. 766-767). El poderoso modelo escurialense no sólo propició un rápido cambio tipológico y estilístico (6), sino que tuvo una repercusión directa en el proceso de construcción de otras cúpulas españolas, todavía en el siglo xvı. Este trabajo pretende evidenciar esa influencia y estudiar el caso de la cúpula de la Capilla Cerralbo de Ciudad Rodrigo, trazada por Juan de Valencia, discípulo de Juan Bautista de Toledo y Juan de Herrera en El Escorial.

\section{EL ESCORIAL Y LA CONSTRUCCIÓN DE CÚPULAS EN ESPAÑA A FINALES DEL SIGLO XVI}

En 1592 se firmaban las Condiciones para la construcción de la cúpula de la iglesia del Colegio de Nuestra Señora de la Antigua en Monforte de Lemos, que definían
The Escorial's dome, built between 1579 and 1582 (1, p. 495 y 505), brought about the consolidation of the Renaissance dome on tambour typology in Spain. The vestry of the church of San Miguel in Jerez de la Frontera, finished by Hernan Ruiz el Joven in 1564 (2, p. 172), could be considered as an earlier example, although the external dimensions of the tambour make it independent from the whole.

Stresses in a fabric building are small and stability is then a problem of equilibrium, strongly connected to geometry: if a thrust line inside the fabric is found, the building will be safe (3, pp. 434-435). In the case of a dome on tambour, which takes on its own the task of thrusts counteracting because there are not surrounding vaults, the project of the section is key. Structural design in the $16^{\text {th }}$ century still had an empirical basis, by copying rules from existing buildings. Constructing the first domes on tambour in Spain must have been a challenge due to the lack of former examples. The available graphical documentation would initially be just the one included in classical treatises on Antiquity and Renaissance models. Those drawings would be not only an architectural reference model but also a structural designing pattern.

The influence of the Escorial's dome would be increased by publishing the Estampas in 1589, drawings of the building by Juan de Herrera including a cross section of the main dome. The Estampas show important differences from what is actually built, although the building was already finished when they were drawn: they present a cupola with a higher tambour and lantern and a thicker dome (4, pp. 457-458; 5, pp. 766-767). The powerful Escorial's model brought about not only a rapid typological and stylistic change but also caused a direct influence in the construction process of other Spanish domes that were being built at the end of the $16^{\text {th }}$ century. This work aims to show this influence and to study the cupola of the Cerralbo Chapel in Ciudad Rodrigo, initially designed by Juan de Valencia, pupil of Juan Bautista de Toledo and Juan de Herrera at the Escorial.

\section{THE ESCORIAL AND THE CONSTRUC- TION OF DOMES IN SPAIN AT THE END OF THE 16TH CENTURY}

Conditions to build the church of the School of Nuestra Señora de la Antigua in Monforte de Lemos, defining a hemispherical dome covered with a pyramidal roof, were signed in 1592 (6, p. 57). Nevertheless, a drum was then added, elevating the dome almost $2,5 \mathrm{~m}$ over the initial level, and the roof was 
una media naranja cubierta con un cimborrio ochavado (6, p. 57). Sin embargo, después se añadía un tambor que eleva la cúpula casi $2,5 \mathrm{~m}$ sobre el nivel inicial y se sustituía el cimborrio por una media naranja pétrea trasdosada al exterior. Con una luz de 10,16 m, el diseño de la sección podría tener relación con las propuestas de Serlio en cuanto a la forma de la cúpula, con las de Palladio en lo relativo al espesor del arranque y con las reglas de Simón García en cuanto a la linterna (7, pp. 100, 25 y 137). Es patente la similitud de proporciones con la cúpula de El Escorial (Figura 1). La configuración constructiva es, sin embargo, diferente: en la mitad inferior de la media naranja escurialense los lechos son horizontales, mientras que en Monforte son radiales (8, p. 772).
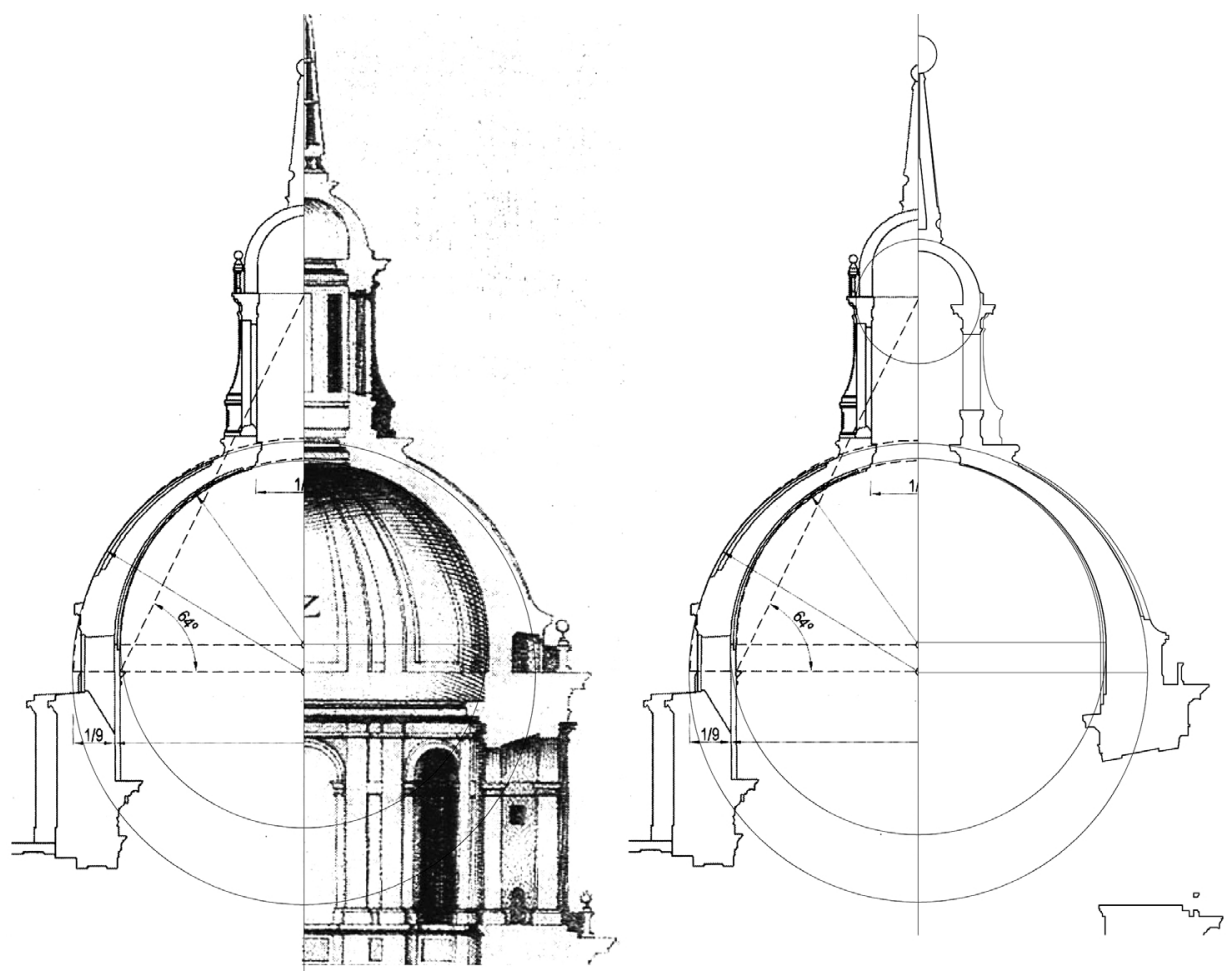

replaced by an extradosed dome. Spanning $10,16 \mathrm{~m}$, the design of the cross section could be related to Serlio's proposals on dome's shape; to Palladio's on thickness at the springing and to Simón García's rules on lantern dimensions (7, p. 100, 25 y 137). Proportions similarities between this dome and the one at the Escorial are evident (Figure 1). Constructive arrangement is, however, different: beds between voussoirs are horizontal in the lower half of the hemispherical dome at the Escorial but at Monforte's they are all radial $(8, p .772)$.
En 1586 se comenzaba el Colegio del Corpus Christi en Valencia, pero la obra se detenía entre noviembre de 1588 y noviembre de 1590, cuando se formalizaba el contrato para la construcción de la iglesia (9, pp. 716-717). Esta paralización quizá tuvo algo que ver con la publicación de las Estampas de El Escorial y un posible proceso de modificación de trazas. La idea inicial era una media naranja sin tambor, y en 1595 todavía se pensaba en un cimborrio, para el que se hacía un modelo de madera: finalmente se terminaba en 1597 la construcción de una media naranja sobre tambor rematada con linterna (6, pp. 5657). Sin embargo, no se trata de una cúpula estrictamente trasdosada, pues está recu-
The construction of the Corpus Christi's School in Valencia started in 1586, but works were interrupted between November 1588 and November 1590 when the contract to build the church was signed (9, pp. 716-717). This standstill was perhaps related to the publishing of the Escorial's Estampas and a possible process of project modification. The initial idea was a hemispherical dome without drum, and even in 1595 a wooden model was made for it, but it was a dome on tambour with lantern what was finally finished in 1597 (6, pp. 56-57). It is not an extradosed dome, as it is tiled roofed, and, unlike the models discussed thus far, the whole cupola is brick made (Figure 2, left).
1. Comparación de proporciones entre las cúpulas del Colegio de Nuestra Señora de la Antigua en Monforte de Lemos (8, p. 771) y El Escorial: a la izquierda con la versión de ésta recogida en las Estampas, y a la derecha con la cúpula construida ( 4 y 5). En ambos casos se ha hecho coincidir centro y radio de las esferas de intradós.

1. Comparison of proportions between the domes at the School of Nuestra Señora de la Antigua in Monforte de Lemos (8, p. 771) and at the Escorial: on the left with the version of this one shown in the Estampas, and on the right with the dome actually built (4 and 5). In both cases scales have been changed in order to match centre and radius of the intrados of both domes. 
2. A la izquierda, cúpula de la iglesia del Colegio del Corpus Christi en Valencia (comarcarural.com); a la derecha, cúpula de la iglesia de los santos Justo y Pastor en Granada (Miguel Roa y flickr.com).

2. On the left, dome of the Corpus Christi's School in Valencia (comarcarural.com); on the right, dome of the church of San Pablo and San Justo in Granada (Miguel Roa and flickr.com). bierta de teja y, a diferencia de los modelos analizados hasta ahora, el conjunto es de ladrillo (Figura 2, izquierda).

En 1589 se inauguraba el cuerpo del templo del Colegio de San Pablo en Granada, hoy iglesia de los santos Justo y Pastor. Las obras se interrumpían entonces, al parecer por falta de recursos económicos, y el trabajo en el crucero se reanudaba en 1618 , con nuevas trazas para reproducir "un modelo en pequeño de la iglesia de S. Pedro de Roma y de la del Escorial", aunque inicialmente ya estaba prevista una cúpula, terminándose en 1622 (10, pp. 174-178; 10, pp. 58-59). Bustamante y Marías señalan, analizando los elementos formales del interior de la cúpula, que no se copió la realidad construida en El Escorial, sino lo que reflejan las Estampas (6, p. 59). El paralelismo con la cúpula herreriana es más claro en el tambor que en la calota, de perfil apuntado y poderosos nervios exteriores (Figura 2, derecha).

En 1587 comenzaba la construcción del crucero de la iglesia de S. Sebastián en Cobos (Segovia), cubierto por una media naranja de cantería trasdosada y peralta$\mathrm{da}$, de $6,40 \mathrm{~m}$ de diámetro, rematada por linterna. Diego de Matienzo se encargaba de la construcción al menos desde 1591 hasta su fallecimiento en 1594; entonces prosiguió su yerno, Diego de Sisniega. Ambos habían sido destajeros en la obra de la iglesia de El Escorial (11, pp. 23 y 26-27): Matienzo ejecutaba una de las partidas que comprendía una cuarta parte de la cúpula principal y Sisniega otra que incluía la torre sur, cubierta con una media naranja trasdosada sobre tambor, y una cuarta parte del sotacoro con su bóveda plana, que finalmente construiría en su totalidad, terminándolo en 1583 (1, pp. 281, 296, 494-498 y 591). La cúpula de Cobos es de una sola hoja y espesor constante, de unos $6,40 \mathrm{~m}$ de luz, construida por lechos horizontales en la parte inferior, al modo de los jarjamentos góticos y las cúpulas escurialenses (11, pp. 27-28) (Figura 3).
The naves of the church of San Pablo's School in Granada, nowadays church of San Pablo and San Justo, were opened in 1589. Works were interrupted then, apparently because of lack of funds. They were restarted at the crossing in 1618 following a new project to reproduce "a model in smaller size of the church of St. Peter's in Rome and the one at the Escorial", although a dome was scheduled from the beginning, being finished in 1622 (10, pp. 174-178; 10, pp. 58-59). Bustamante and Marías point out, attending to the design of the cupola's interior, that they did not copy what was actually built at the Escorial but what is shown in the Estampas (6, p. 59). The evidences of the similarities with Herrera's dome are clearer analyzing the tambour more than the dome itself, which has a pointed profile and powerful external ribs.

The construction of the curch's crossing of San Sebastián in Cobos (Segovia) began in 1587. It is a hemispherical extradosed stone dome spanning 6,40 m, topped by a lantern. Diego de Matienzo was in charge of the construction at least since 1591 until his death in 1594; then his son-in-law Diego de Sisniega took the responsibility. Both of them had been contractors at the Escorial's church works (11, pp. 23 y 26-27): Matienzo constructed one of the parties comprising a quarter part of the main dome and Sisniega another one including the southern tower, covered with a hemispherical extradosed dome on tambour, and the flat vault at the forechurch, finished in 1583 (1, pp. 281, 296, 494-498 y 591). The dome at Cobos has a solid structure with constant thickness and the lower part is constructed by horizontal beds, as it was in Gothic tasde-charges and Escorial's domes $(11$, p. 2728) (Figure 3).

The dome built at Cobos shows important differences with the Escorial's one: constant and thinner thickness, no projections in both intrados and extrados and the course where beds configuration changes from horizontal
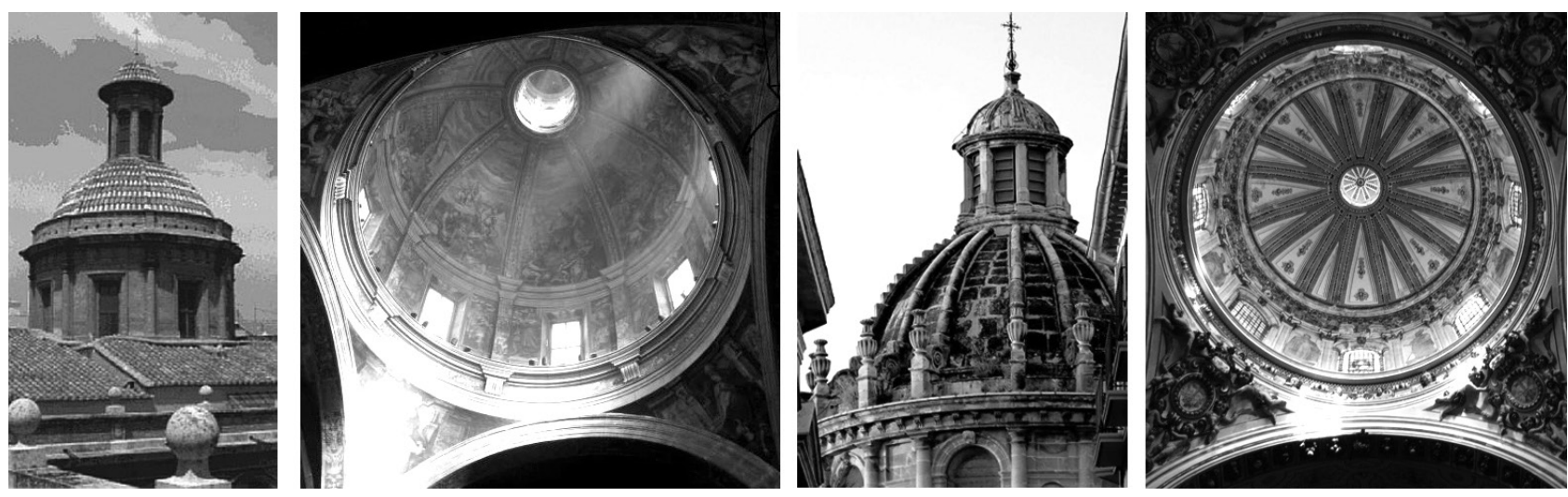
En Cobos se construyó una cúpula con diferencias notables frente a las escurialenses: espesor constante y más delgado, trasdós e intradós sin resaltos y la hilada de cambio de lechos horizontales a radiales con menor altura en el interior. En El Escorial esta hilada se mantenía regular en el interior y más alta al exterior (11, pp. 27-28). Diego de Sisniega construiría otra cúpula trasdosada a partir de 1601 en la torre del Monasterio de Irache en Navarra (12, pp. 120121) (Figura 4).

\section{LA CAPILLA CERRALBO DE CIUDAD RODRIGO}

La construcción de la Capilla había comenzado hacia 1585, siendo aparejador Juan de Balbás. En 1595 se contrataba a Juan de Ribero Rada, entonces maestro mayor de la catedral nueva de Salamanca, obligándole to radial is lower in the internal face. The same course at the Escorial has a regular internal size and a higher external one (11, pp. 27-28). Diego de Sisniega would build another extradosed dome starting in 1601 in the tower of the Monastery of Irache in Navarra (12, pp. 120-121) (Figure 4).

\section{CERRALBO CHAPEL IN CIUDAD RODRIGO}

The construction of the chapel had begun around 1585, being Juan de Balbás master mason of the works. In 1595 Juan del Ribero Rada, architect of the Salamanca's new cathedral, was contracted to follow the existing project by Juan de Valencia, who had died in 1591 (14, p. 206). But Ribero died in 1600 and there is no documentation on his successor or on the continuity of the master mason. Altarpieces for presbytery

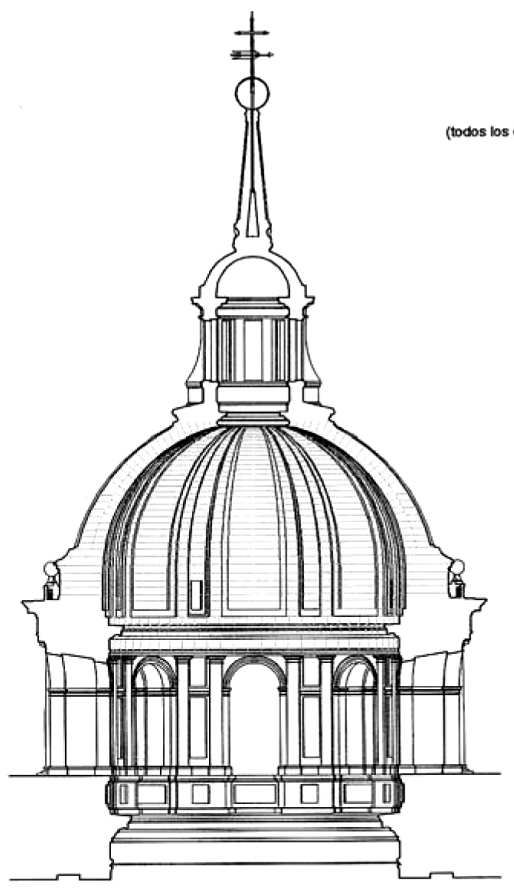

INF IZQ-SECCION DE LA CUPULA DE LA BASILICA DE EL ESCORIAL

INF CEN - SECCION DE LA CUPULA DE LA TORRES SUR DE LA BASILICA DEL EL ESCORIAL

INF DCH - SECCION TRANVERSAL DE LA IGLSLA DE COBOS DE SEGOVIA
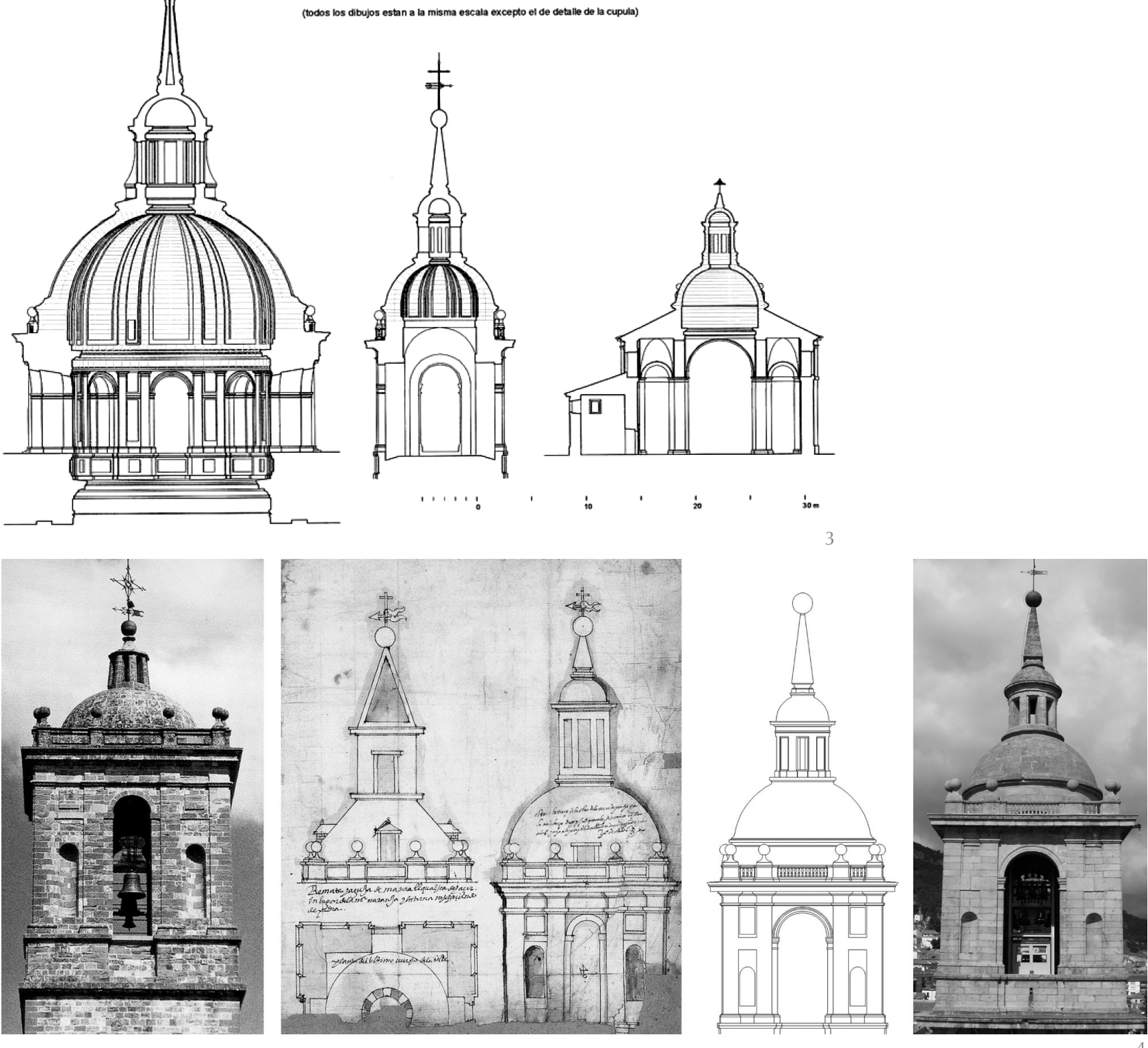
5. Estado de la cúpula de la Capilla Cerralbo antes y después de la restauración de 1889 (dibujos conservados en la sacristía de la iglesia).

5. State of the dome of Cerralbo Chapel before and after the 1889 restoration (drawings kept at the church's vestry). a seguir las trazas existentes de Juan de Valencia, quien había fallecido en 1591 (14, p. 206). Ribero murió en 1600 y no hay datos sobre su sucesor ni sobre la continuidad del aparejador. Los retablos del presbiterio y transepto estarían colocados antes de 1658 y el crucero por tanto terminado, pero la Capilla no se consagraba hasta 1685: el retraso pudo deberse a la necesidad de reparar los graves daños ocasionados por un rayo. En 1818 explotó el polvorín que se había almacenado en la iglesia durante la Guerra de la Independencia, causando serios desperfectos (14). La parte más dañada fue la cúpula, que "tras volar por los aires volvió a caer a plomo sobre su base, totalmente cuarteada y destrozadas la balaustrada exterior y la linterna" (15, p.16). Se procedió a la restauración mucho más tarde, no quedando abierta al culto hasta 1889. En la sacristía de la iglesia se conservan unos dibujos que reflejan el estado de la cúpula antes y después de esta intervención (Figura 5).

Entre 1995 y 1996 se hicieron otras obras de restauración que incluyeron la cubrición exterior de la media naranja y el cupulín de la linterna con planchas de plomo. En las reparaciones de 1889 se debió de colocar el tirante metálico que reflejan los dibujos de la Figura 5, para limitar la apertura de la cúpula, de la que nos hablan las grietas meridianas que se observan en el intradós. Un tirante era visible en 1975, antes de la cubrición del trasdós (Figura 6, izquierda). and transept were placed before 1658, so the crossing had to be finished at that moment. Nevertheless the Chapel wouldn't be devoted until 1685: perhaps the delay was due to the need of repairing the severe damages caused by a lightning. A powder keg that had been kept in the chapel since the Independence War exploded in 1818 causing serious damages (14), specially in the dome, which "after flying went down again onto its base, completely cracked and being destroyed the external balustrade and the lantern" $(15$, p. 16). The restoration was carried out much later and the chapel wouldn't be opened until 1889. Drawings that show the state of the dome before and after restoration are kept at the church's vestry (Figure 5).

Repairing works including the covering of the dome and lantern with lead plates were carried out between 1995 and 1996. The metal rod that the drawings of Figure 5 show could likely be placed during the restoration of 1889 to restrict the dome spreading: meridian cracks existing now in the intrados make this process evident. A metal rod could be seen in the extrados in 1975, before the covering of the dome (Figure 6, left).

Juan de Valencia was a stepson of the architect Luis de Vega, who recommended him just before his death in 1562 to the king Philip II. Valencia was co-author of most of the drawings at the Escorial. In 1590 he was designing the church and cloister of the

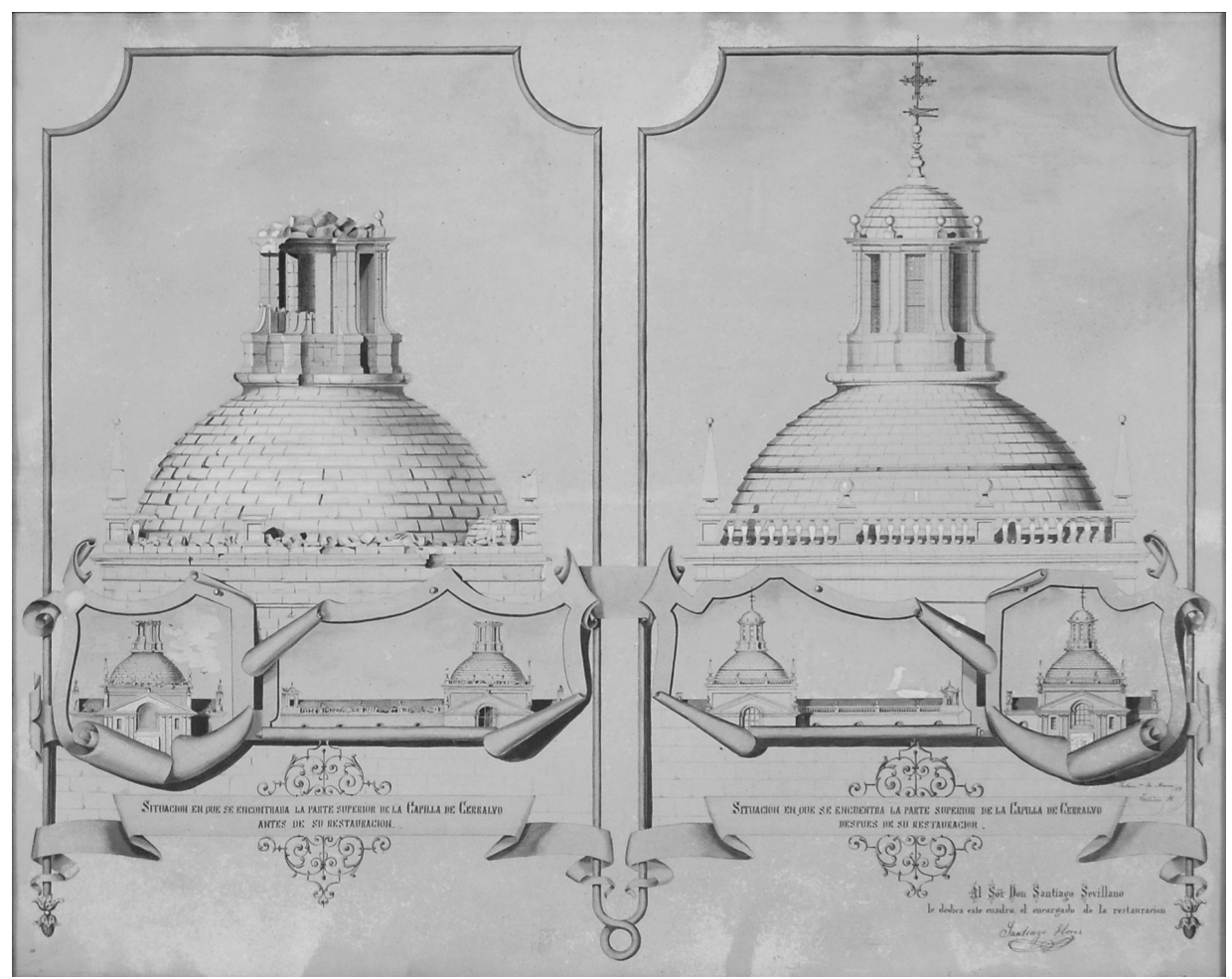


Juan de Valencia era hijastro del arquitecto Luis de Vega, quien al morir en 1562 lo recomendó a Felipe II. En El Escorial participaba en la elaboración de la mayoría de las trazas. En 1590 diseñaba la iglesia y el claustro de la Trinidad Calzada en Madrid, que no se conservan (14, pp. 202-203). Su experiencia en la construcción de cúpulas sería, pues, la adquirida en El Escorial.

Es difícil precisar el grado de intervención de Juan del Ribero Rada (1540-1600) en el proyecto de la Capilla Cerralbo. Era sobrino de Nicolás del Ribero, destajista en El Escorial en una de las partidas de la cúpula principal. Colaborador habitual de Rodrigo Gil de Hontañón, su obra fue prolífica (16, pp. 88-101), pero no habría participado en proyectos de construcción de cúpulas renacentistas, por lo que sería extraño que hubiera modificado en lo fundamental las trazas de Valencia. Fernando Marías, atendiendo a la configuración estilística de los paramentos interiores, señalaba que Juan del Ribero habría rediseñado el proyecto de Juan de Valencia (17, pp. 550-553).

\subsection{Configuración geométrica}

La Capilla fue objeto de un levantamiento dirigido por Juan Carlos Arnuncio Pastor, que cristalizaba en una serie de cuidadosos dibujos de planta, secciones longitudinal y transversal por el crucero y alzados principal y lateral (18, láms. XXI-XXIII). Los objetivos de este trabajo aconsejaron realizar un nuevo levantamiento del crucero para obtener datos precisos sobre la geometría y corte de piedra de la cúpula. La toma de datos topográfica, efectuada en diciembre de 2012, se llevó a cabo con una estación total láser (Figura 7).

La nave y el transepto, de la misma anchura, definen un crucero de planta cuadrada cubierto por una media naranja peraltada apoyada sobre cuatro pechinas que arrancan de los arcos torales (Figura 8). El diseño de las pilastras que recubren los pilares del crucero tiene sus consecuencias en la determinación de la cúpula: en su alzado frontal se van es-
Trinidad Calzada in Madrid, unpreserved nowadays (14, p. 202-203). His experience in domed construction would be then only that acquired at the Escorial.

It is hard to determine how much Juan del Ribero Rada (1540-1600) participated in the project of Cerralbo Chapel. He was nephew of Nicolás del Ribero, contractor at the Escorial of a party comprising a quarter of the main dome. Associate of Rodrigo Gil de Hontañón, his work was prolific (16, p. 88101), but he wouldn't have participated in projects concerning construction of Renaissance domes, so it would be unlikely that he would have changed the initial project by Juan de Valencia in its key aspects. Fernando Marías, attending to the stylistic configuration of internal walls of the church, pointed out that Juan del Ribero Rada would have redesigned Valencia's project (17, pp. 550-553).

\subsection{Geometrical configuration}

An architectural surveying of the Chapel was commanded by Juan Carlos Arnuncio Pastor, generating a set of careful drawings including plans, cross sections along the crossing and main and side elevations (18, plates XXI-XXIII). The objectives of the present work took to carry out a new surveying in order to obtain accurate data on geometry and stone cutting of the dome. The data collection was made in December 2012 using a laser total station (Figure 7).

Nave and transept are of the same width, defining a squared plan crossing covered by an elevated hemispherical dome supported by pendentives over the crossing arches (Figure 8). The design of the pilasters over the crossing piers has consequences in the dome: in their front elevation they get uniformly narrower bottom-up, increasing the horizontal distance between each pair of facing crossing arches which spring as a continuation of the top of the pilasters. The span of the dome is then also wider, as it is vertically aligned with the crossing arches. Crossing piers and cylindrical base of the
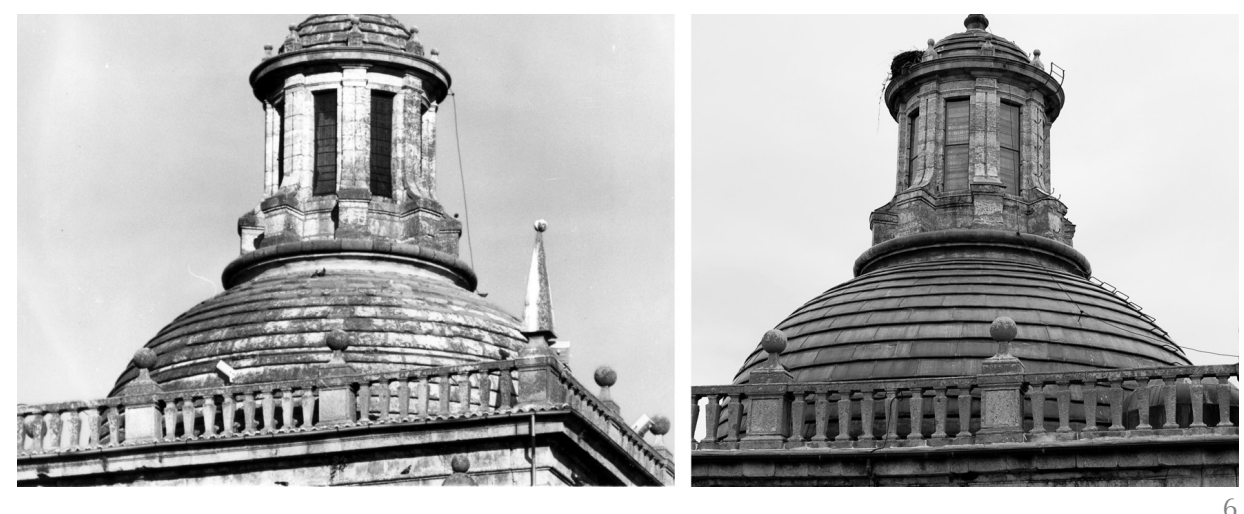

6. A la izquierda fotografía de 1975 (Agustín Bustamante García); a la derecha, estado de la cúpula en diciembre de 2012 (fotografía de la autora).

6. On the left, 1975 photograph (Agustín Bustamante García); on the right, state of the dome on December 2012 (photograph by the author). 
7. Nube de puntos obtenida con estación total láser.

7. Point cloud measured with a laser total station.

8. Interior de la Capilla Cerralbo (fotografía de la autora).

8. Interior view of Cerralbo Chapel (photograph by the author). trechando desde la basa hasta el capitel uniformemente, lo que aumenta la separación horizontal de los arcos torales, que están trazados como prolongación de la parte superior de las pilastras, y por tanto el diámetro de la cúpula, que está a plomo con ellos.

Los pilares del crucero y el peralte de la cúpula no presentan desplome apreciable. La luz de la media naranja no habría aumentado entonces por movimientos de los elementos que la soportan: el diámetro del peralte, del que parten enrasados los resaltos principales del intradós que simulan pilastras pareadas, es de 10,54 m.

Para proponer una traza de la sección de la media naranja ha sido necesario considerar posibles movimientos, que desvían el estado actual de lo que realmente se proyectó. La posición media del perfil de intradós en el conjunto de puntos medidos supone un descenso de la parte superior y una apertura de la zona central hacia el exterior. Sin desplomes de los elementos inferiores, este movimiento sólo es posible por un giro en el arranque, una deformación de la cimbra o aplastamientos de las juntas. Recordemos en este punto que la cúpula quedó seriamente dañada por la explosión del polvorín en 1818. Además, la zona de máxima apertura horizontal coincide aproximadamente con la posición del tirante que se colocó alrededor del trasdós hacia 1889. Con el mismo argumento de deformación se ha propuesto una traza para el trasdós, definido por una esfera de $12,54 \mathrm{~m}$ de diámetro (45 p). Su centro está 0,84 m más bajo que el del intradós (3 p), por lo que la sección tiene espesor decreciente hacia la clave. La inspección directa realizada en el trasdós ha permitido comprobar que el chapado de dome do not show measurable slant. The span of the hemispherical dome wouldn't have then increased because of the movements of the elements supporting it. The diameter of its cylindrical base, which is vertically aligned with the main intrados projections recalling a couple of pilasters, is $10.54 \mathrm{~m}$.

In order to propose a layout for the dome cross-section it has been necessary to take into account possible movements that make the current state different from what was actually projected. The average position of the intrados profile in the set of measured points means a descent of the upper part and a spreading of the central one to the exterior. Without slant of the elements supporting the dome, this movement is only possible after a rotation at the springing, a centering deformation or a flattening of the joints. We should remember at this point that the dome was seriously damaged by the 1818 explosion of the powder keg. The area of maximum horizontal spreading approximately matches the position of the metal rod placed around 1889. Following the same reasoning a layout for the extrados has been posed, defining a $12.54 \mathrm{~m}$ diameter sphere $(45 \mathrm{ft})$. Its centre is 0.84 $m(3 \mathrm{ft})$ lower than that of the intrados, so the thickness decreases upwards. A direct inspection of the extrados has allowed checking that the lead plates follow the shape of the overlapped voussoirs, as stone can be seen behind the edges of the plates. The extrados profile has been drawn following the measured points on the lead plates and adapting them to the mentioned layout for the extrados (Figure 9). Figure 10 shows plans and section of the crossing after the surveying carried out for this paper.
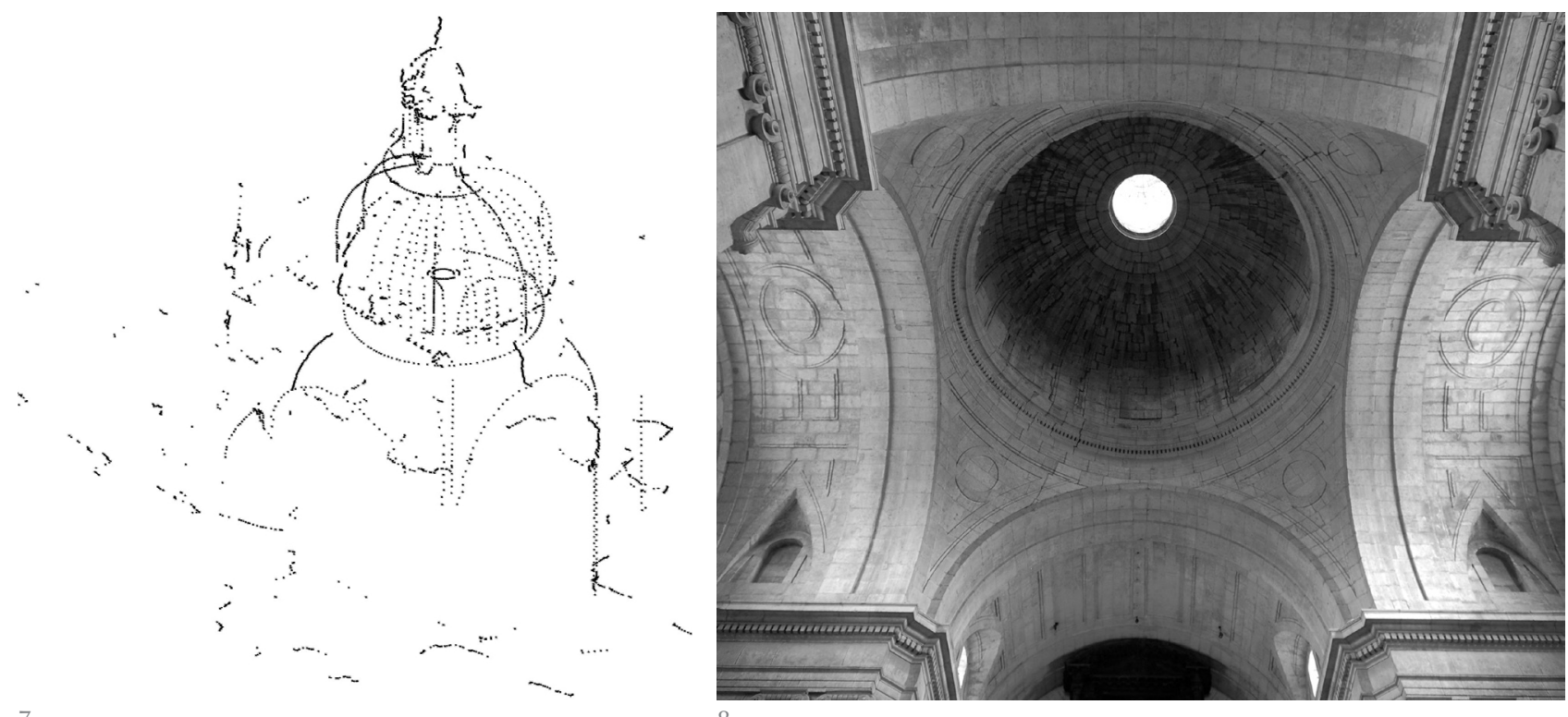

8 
plomo sigue el perfil de las dovelas solapadas, pues la piedra es visible por debajo de las rebabas de la chapa. Como perfil del trasdós se ha trazado una directriz similar a la del chapado de plomo, que es lo que se ha podido medir, adaptada al perfil exterior propuesto (Figura 9). En la Figura 10 se ofrecen plantas y sección del crucero, fruto del levantamiento realizado para este trabajo.
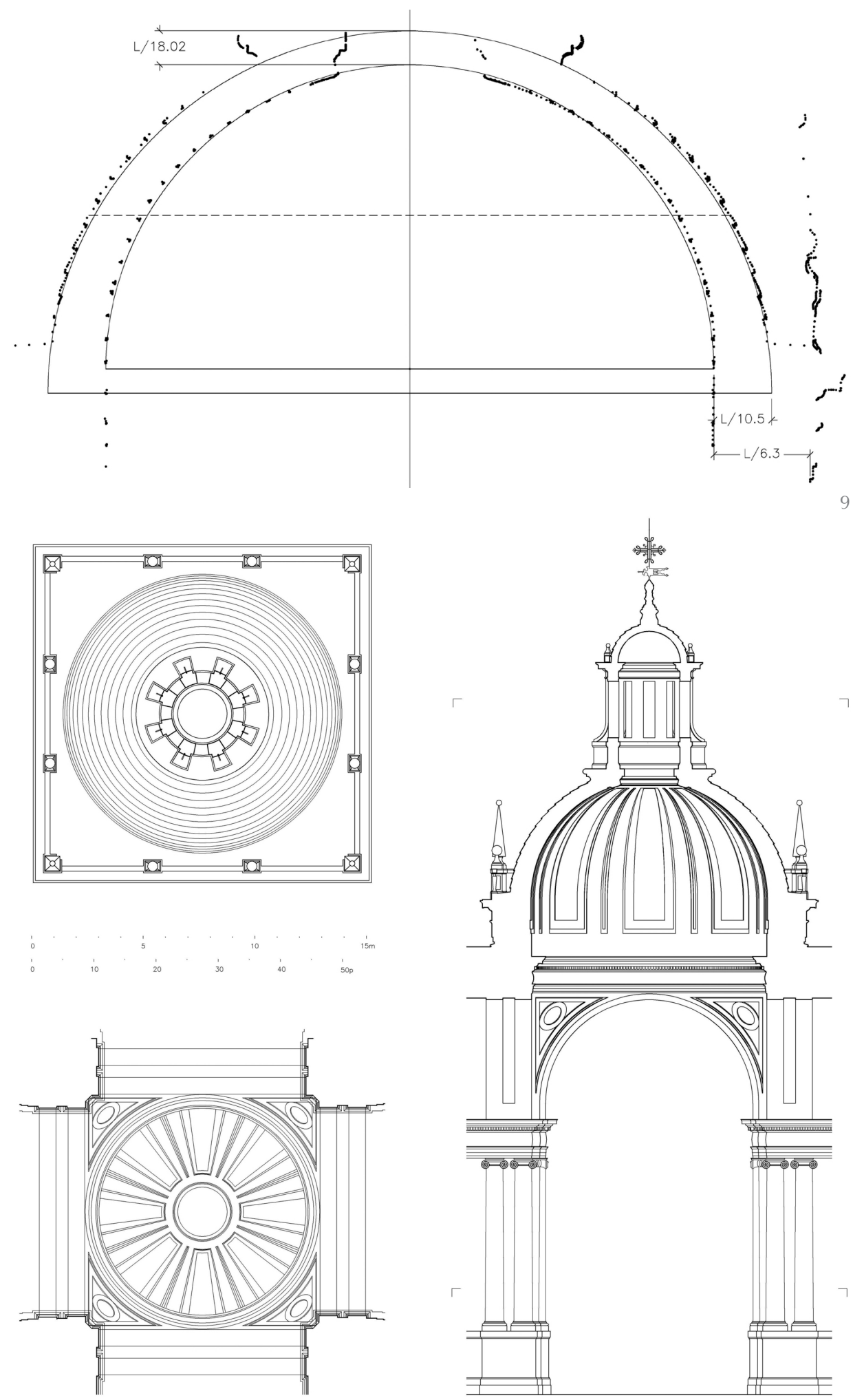

9. Puntos medidos y trazado propuesto para el perfil de la cúpula. La línea horizontal a trazos indica la posición del tirante colocado en 1889.

9. Measured points and proposed layout for the dome profile. The horizontal dashed line indicates the position of the metal rod placed in 1889.

10. Plantas y sección del crucero de la Capilla Cerralbo en Ciudad Rodrigo, fruto del levantamiento realizado para este trabajo.

10. Plans and section of the crossing after the surveying specifically carried out for this paper. 
11. Configuración constructiva de la cúpula de la Capilla Cerralbo en Ciudad Rodrigo. En la mitad derecha se han superpuesto los puntos de medición de las hiladas.

11. Constructive arrangement of the dome of Cerralbo Chapel in Ciudad Rodrigo. On the right the joints measured points have been overlapped.

\subsection{Configuración constructiva de la media naranja}

La inspección directa del trasdós permitió comprobar que las juntas entre hiladas están situadas tras el solape. Así, se ha podido proponer una hipótesis de disposición de los lechos, que serían horizontales hasta una hilada de cambio, con menor altura en el intradós, señalada en la Figura 11 con sombreado oscuro (11, p. 28). A partir de ella los lechos serían cónicos, pero el vértice en las cuatro primeras no estaría situado en el centro del intradós, sino 0,42 m más alto (1,5 p): esa menor inclinación favorecería el proceso de puesta en obra, al dificultar el deslizamiento (hiladas con sombreado claro en la Figura 11). Esta disposición se mantiene hasta los $33^{\circ}$ de inclinación: en la cúpula de El Escorial también hay un cambio a ese nivel; a partir de $32^{\circ}$ los lechos pasan de ser horizontales a radiales $(5$, p. 770$)$.

\subsection{Constructive arrangement of the dome}

A direct inspection of the extrados allowed checking that joints between different courses are placed just behind the overlapping. It has then been possible to pose a hypotheses on beds layout, which would be horizontal up to a course with a lower height in the intrados, marked with a dark hatch in Figure 11 (11, p. 28). There from beds would follow a conical directrix, but the vertex of the first four ones would not match the centre of the intrados but a point $0.42 \mathrm{~m}(1.5 \mathrm{ft})$ higher: that smaller inclination would be an advantage for placing the voussoirs, as it hinders the sliding (courses with light hatch in Figure 11). This arrangement is maintained up to an inclination of $33^{\circ}$ : at the Escorial's dome there is also a change at that level: from an inclination of $32^{\circ}$ the beds are set following a radial alignment $(5$, p. 770$)$.

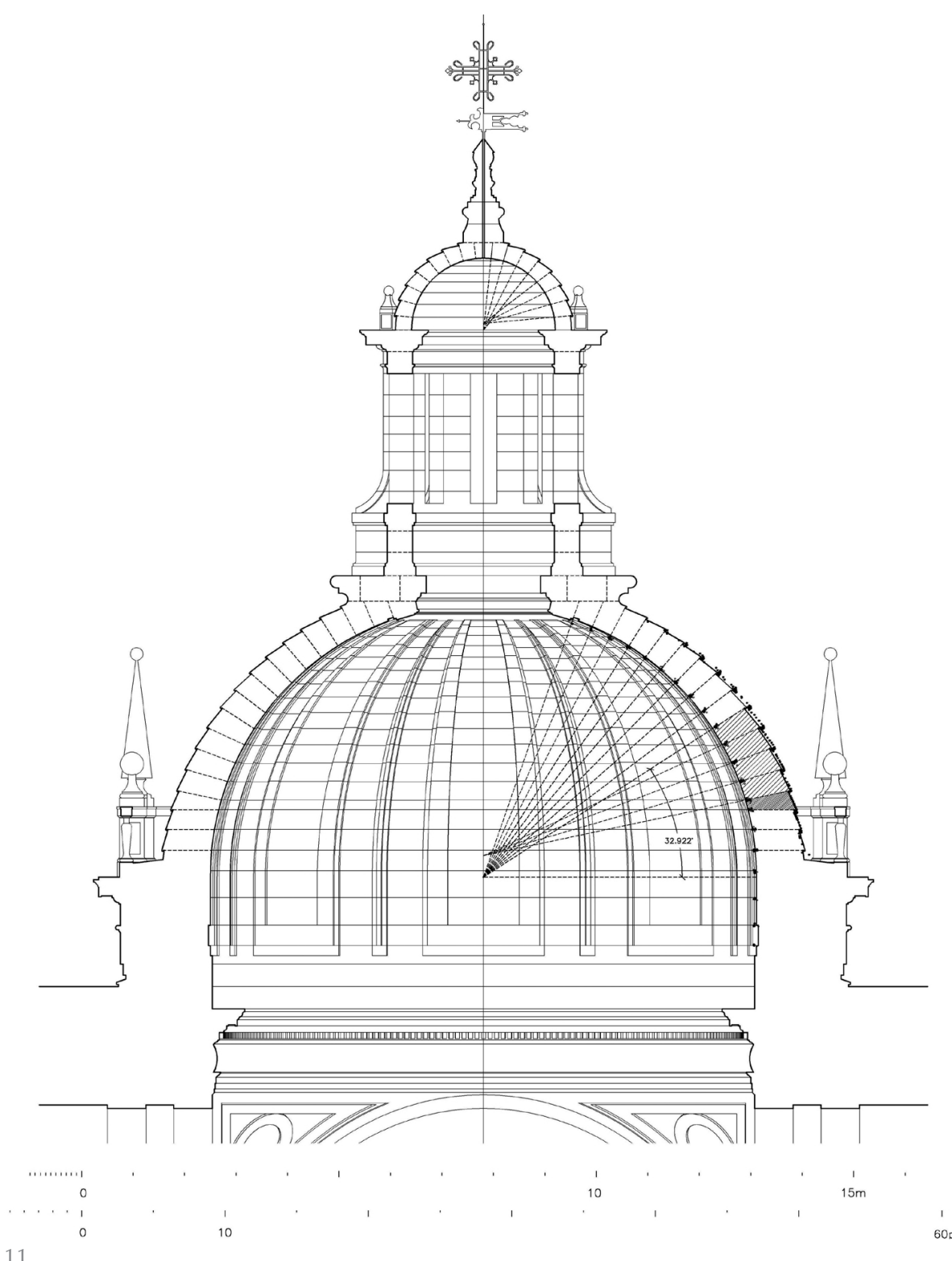


La existencia o no de alineación radial de juntas exteriores e interiores entre dovelas de la misma hilada permitiría determinar la existencia de una o más hojas de bóveda. Sin embargo, al no estar visibles aquí las exteriores, esta cuestión no ha podido ser dilucidada. Uno de los primeros testimonios gráficos del uso de dovelas solapadas está en las trazas para el remate de la torre de las campanas de la catedral de Lugo, realizadas por Gaspar de Arce en 1570 (19, p. 161).

\subsection{Comparación con otras cúpulas}

La comparación de los perfiles de las cúpulas de Ciudad Rodrigo y El Escorial permite apreciar que el espesor del peralte y la mitad superior de la media naranja son proporcionales, pero en la primera la cúpula en el arranque es más delgada y la linterna más alta $y$, fundamentalmente, se ha suprimido el tambor (Figura 12).
It would be possible to determine the existence of a double internal dome structure checking the alignment of internal and external joints in each course. But, as external ones are not currently visible this issue could not be analyzed. One of the earliest graphical evidences on the use of overlapped voussoirs can be found in the available original project by Gaspar de Arce for the bell tower at Lugo's cathedral (19, p. 161).

\subsection{Comparison with other domes}

Comparison between the profiles of the domes of Ciudad Rodrigo and the Escorial allows realizing that the thickness of the cylindrical base and the upper part of the dome are proportional; but in the first one the dome is thinner at the springing and the lantern is higher and, mainly, the tambour has been discarded (Figure 12).

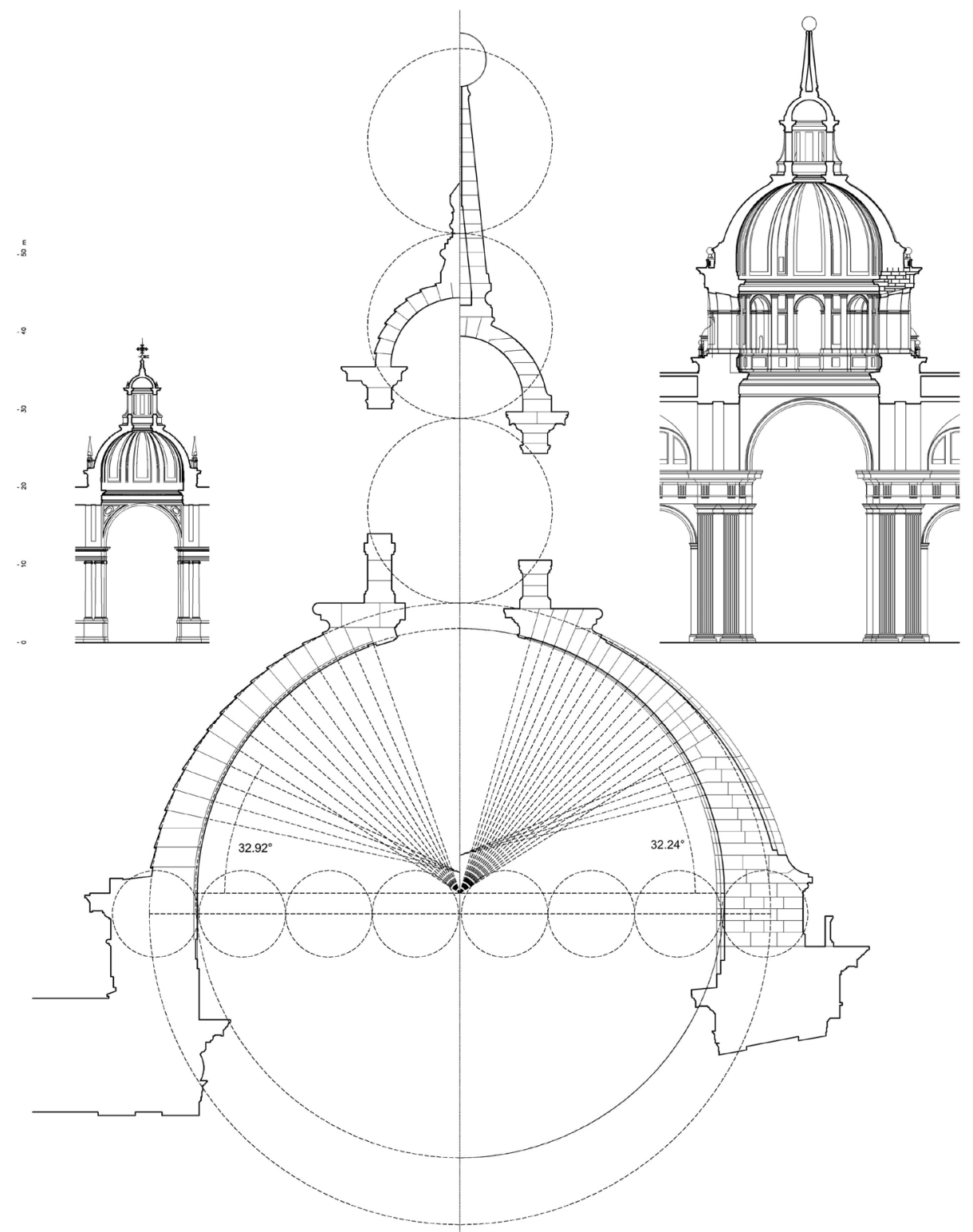


13. De izquierda a derecha, comparación de proporciones entre la cúpula de la Capilla Cerralbo y las trazas de Pedro de Brizuela para la torre del campanario y el crucero de la catedral de Segovia (20, pp. 37 y 39), y la cúpula construida en el crucero de la misma catedral $(22$, p. 61). En los dibujos se ha hecho coincidir centro y radio del intradós.

13. From left to right, comparison of proportions between the dome of Cerralbo Chapel and Brizuela's layouts for the bell tower and crossing of Segovia's cathedral (20, pp. 37 y 39), and the dome actually built at the crossing of the same cathedral (22, p. 61). The drawings have been made matching centre and radius of the intrados of both domes.
La torre y el crucero de la catedral de Segovia están cubiertos con cúpulas trasdosadas de cantería, con dovelas solapadas. Se conservan trazas originales de ambos proyectos, realizadas por Pedro de Brizuela en 1614 y 1630 respectivamente (20, p. 3639). La primera muestra una cúpula proporcionalmente más gruesa y con una linterna más esbelta -pero de diámetro similar-que la de Ciudad Rodrigo. La configuración constructiva tiene más paralelismos: el espesor de la media naranja es decreciente hacia la clave, cuestión ya señalada por Pizzi respecto a la traza segoviana (21, p. 1125), las cuatro primeras hiladas tienen sus lechos cónicos convergentes hacia un punto más alto que el centro del intradós y las dovelas son solapadas por el trasdós. La segunda muestra más coincidencias con la Capilla Cerralbo: el espesor es también decreciente $(21$, p. 1123$)$ pero la proporción de la media naranja es muy similar, lo mismo que el tamaño de las dovelas y su remate solapado (Figura 13).

La cúpula de Ciudad Rodrigo es más gruesa en el arranque que la del crucero de la catedral de Segovia (22, p. 61): el diámetro de la linterna es similar y la segunda muestra también un ligero decrecimiento del espesor hacia la clave. Además, la disposición final sobre una terraza cuadrada de la cúpula construida en el crucero segoviano es similar a la de la Capilla Cerralbo. En ambos casos no se puede hablar estrictamente de tambor (Figura 13). En el paso desde la traza de Brizuela hasta la cúpula construida se disminuyó el diámetro del trasdós aproximadamente $30 \mathrm{~cm}$ y se elevó su centro $41 \mathrm{~cm}$.
The tower and crossing of Segovia's cathedral are both covered with extradosed stone domes with overlapped voussoirs. Original drawings of both projects by Pedro de Brizuela (1614 and 1630) are preserved (20, p. 36-39). The tower layout shows a proportionally thicker dome and a higher lantern -with similar diameter- than that of Ciudad Rodrigo. The constructive arrangement presents more similarities: the thickness of the dome decreases upwards, as Pizzi pointed out on Segovia's layout (21, p. 1125); the beds of the first four courses are aligned with a point higher than the centre of the intrados and the voussoirs are overlapped. The crossing layout shows more coincidences with that of Ciudad Rodrigo: the thickness also decreases upwards (21, p. 1123) but the proportion of the dome is similar as they are the size of the voussoirs and their overlapping (Figure 13).

The dome at Ciudad Rodrigo is thicker at the springing than that of Segovia's cathedral crossing (22, p. 61): the lantern diameter is similar and the second shows also a light thickness decreasing upwards. The arrangement over a squared terrace is also similar. In both cases there is not a real tambour (Figure 13). In the process from Brizuela's layout to what was actually built the extrados diameter was decreased approximately $30 \mathrm{~cm}$ and the centre was elevated $41 \mathrm{~cm}$.
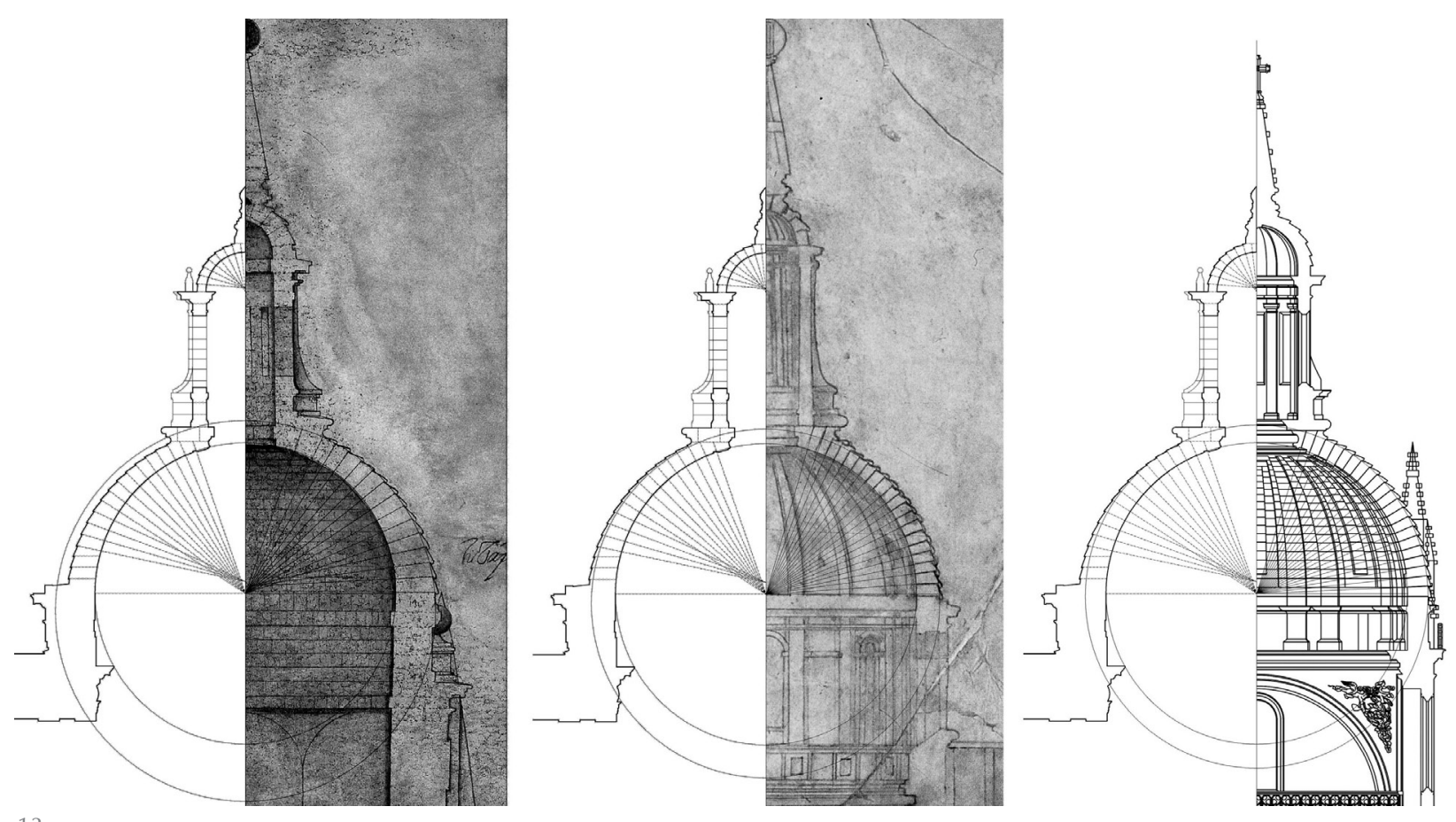


\section{CONCLUSIONES}

Analizada la influencia directa de El Escorial en los ejemplos más significativos que se construían a finales del siglo XVI, se han podido constatar ciertas evidencias. En Monforte de Lemos se sustituyó el proyecto inicial de cimborrio por una cúpula trasdosada cuya sección es proporcional a la escurialense. En el Colegio del Corpus Christi en Valencia, tras una paralización de las obras en marcha, se sustituía el cimborrio inicial por una cúpula trasdosada sobre tambor. Las obras de la iglesia de los santos Justo y Pastor en Granada se paralizaban en 1589 y en 1618 se daban nuevas trazas con idea de reproducir en pequeño "la iglesia de S. Pedro de Roma y de la del Escorial". Diego de Sisniega, que había participado en la construcción de las torres y el sotacoro de El Escorial, construía una torre en el monasterio de Irache muy similar a las escurialenses.

Existen paralelismos entre la cúpula de la Capilla Cerralbo y la de El Escorial: el diámetro de la linterna, los espesores del peralte y la mitad superior de la media naranja son proporcionales y la configuración constructiva es similar en la disposición de los lechos, primero horizontales y luego radiales, con cambios desde los $30^{\circ}$ de inclinación. Sin embargo, en la Capilla Cerralbo la cúpula en el arranque es más delgada, la linterna más alta y, fundamentalmente, se ha suprimido el tambor. A pesar de las similitudes con El Escorial, son más patentes las coincidencias con la traza de Pedro de Brizuela para la cúpula del crucero de la catedral de Segovia. Centrado el ámbito de trabajo de este arquitecto en la zona de Segovia, habría que buscar otras conexiones.

Sobre el proyecto estructural de cúpulas se han documentado similitudes de diseño proporcional entre El Escorial y Monforte de Lemos o Ciudad Rodrigo y entre ésta y la traza de Pedro de Brizuela para el crucero de la catedral de Segovia.

Artífices que habían participado en la construcción de El Escorial -Juan de Matienzo, Diego de Sisniega, Juan de Valencia- se embarcaban después en la construcción de otras cúpulas trasdosadas pero sin tambor. Sin embargo, el propio Juan de Herrera no volvería a repetir la experiencia escurialense, proyectando para el crucero de la catedral de Valladolid una bóveda vaída.

\section{AGRADECIMIENTOS}

Este trabajo ha sido realizado en el marco del Proyecto de Investigación "Construcción en piedra de cantería en los ámbitos

\section{CONCLUSIONS}

After analyzing the influence of the Escorial in the most significant examples that were being built at the end of the 16th century, some evidences have been proven. The initial project for the crossing of Monforte de Lemos was replaced by an extradosed dome whose cross-section is proportional to the Escorial's one. The initial idea for the crossing of the Corpus Christi's School in Valencia was a hemispherical dome without drum, but after a work interruption, a tambour was finally built. The works on the church of San Pablo and San Justo in Granada were interrupted in 1589 and a new project to reproduce "a model in smaller size of the church of St. Peter's in Rome and the one at the Escorial" was made in 1618. Diego de Sisniega, who had been a contractor at the works of the church towers and forechurch at the Escorial, built then a very similar tower at Irache's monastery.

There are similarities between the dome at Cerralbo Chapel and the one at the Escorial: the lantern diameter and the thickness of both cylindrical base and upper part of the dome are proportional and the constructive arrangement of the beds is similar; horizontal up to $32^{\circ}$ and radial aligned upwards. Nevertheless, the dome at Cerralbo Chapel is thinner at the springing, the lantern is higher and, mainly, the tambour has been discarded. In spite of the similarities with the Escorial, coincidences with Pedro de Brizuela's layout for Segovia's cathedral crossing are more evident. As the area where this architect fundamentally worked was Segovia, different connections should be investigated.

On structural dome project some similarities on proportional design have been shown between the Escorial and Monforte de Lemos or Ciudad Rodrigo and between the last one and Brizuela's layout for the crossing of Segovia's cathedral.

Architects that had participated in the construction of the Escorial -Juan de Matienzo, Diego de Sisniega, Juan de Valencia- undertook later on the building of extradosed domes now without tambour. Nevertheless, Juan de Herrera himself wouldn't repeat the Escorial's experience, as he covered the crossing of the cathedral of Valladolid with a sail vault.

\section{ACKNOWLEDGEMENTS}

This paper is part of the research project "Ashlar construction in the Mediterranean basin and Atlantic area. Analysis of built 
mediterráneo y atlántico. Análisis de ejemplos construidos" (BIA2009-14350) del Plan Nacional de I+D+i, financiado por el Ministerio de Ciencia e Innovación. Quiero expresar mi gratitud a Ángel Martín CarbaIlo, Agustín Bustamante García, Juan Carlos Arnuncio, Carlos Lerma, Santiago Huerta, Leyre Mauleón y Javier Contreras. heritage", which is funded by the Ministry of Science and Innovation of Spain (BIA2009-14350-C02-01). I wish to show my gratitude to Ángel Martín Carballo, Agustín Bustamante García, Juan Carlos Arnuncio, Carlos Lerma, Santiago Huerta, Leyre Mauleón and Javier Contreras.

\section{REFERENCIAS / REFERENCES}

(1) Bustamante García, A. (1994). La octava maravilla del mundo (Estudio histórico sobre el Escorial de Felipe II). Madrid. Alpuerto.

(2) Morales Martínez, A. J. (1989). Tradición y modernidad, 1526-1563. En Arquitectura del Renacimiento en España, 1488-1599. Madrid. Cátedra: pp. 99-249.

(3) Huerta Fernández, S. (2004). Arcos, bóvedas y cúpulas. Geometría y equilibrio en el cálculo tradicional de estructuras de fábrica. Madrid. Instituto Juan de Herrera.

(4) López Mozo, A. (2009). Tesis doctoral inédita Bóvedas del Monasterio de El Escorial. Manuscrito en la biblioteca de la Escuela Técnica Superior de Arquitectura de la Universidad Politécnica de Madrid.

(5) López Mozo, A. (2009). La cúpula de El Escorial: geometría, estereotomía y estabilidad. En Actas del Sexto Congreso Nacional de Historia de la Construcción. Madrid. Instituto Juan de Herrera: 763-776.

(6) Bustamante García, A. y F. Marías Franco (1985). La sombra de la cúpula de El Escorial. Fragmentos, 4-5: 46-63.

(7) Guerra Pestonit, R.A. (2012). Tesis doctoral inédita Bóvedas y contrarresto del Colegio de Nuestra Señora de la Antigua de Monforte de Lemos: geometría, construcción y mecánica. Manuscrito en la biblioteca de la Escuela Técnica Superior de Arquitectura de la Universidad Politécnica de Madrid.

(8) Guerra Pestonit, R.A. (2009). The dome of the Colegio del Cardenal in Monforte de Lemos (Spain): geometry, construction and stability. En Proceedings of the Third International Congress on Construction History, Cottbus. Chair of Construction History and Structural Preservation of the Brandenburg University of Technology Cottbus: 767-774.

(9) Lerma Elvira, C. con A. Mas Tomás y M. Galiana Agulló (2012). Estudio del proceso constructivo documentado del colegio de Corpus Christi de Valencia. En Actas del Séptimo Congreso Nacional de Historia de la Construcción. Madrid. Instituto Juan de Herrera: 1119-1131.

(10) Rodríguez Gutiérrez de Ceballos, A. (1967). Bartolomé de Bustamante y los orígenes de la arquitectura jesuítica en España. Roma. Institutum Historicum S. I.

(11) Alonso Rodríguez, M. A. (2007). Sobre la cúpula trasdosada de la Iglesia de Cobos en Segovia. En Actas del Quinto Congreso Nacional de Historia de la Construcción. Madrid. Instituto Juan de Herrera: 23-28.

(12) Losada Varea, C. (2007). La arquitectura en el otoño del Renacimiento: Juan de Naveda (1590-1638). Santander. Servicio de Publicaciones de la Universidad de Cantabria.

(13) López Mozo, A. (2002). Las cúpulas de las torres de la iglesia del Monasterio de El Escorial. En Actas del Simposium "El Monasterio de El Escorial y la arquitectura". Madrid. Ediciones Escurialenses: 504-519.

(14) Rodríguez Gutiérrez de Ceballos, A. (1975). La Capilla Cerralbo de Ciudad Rodrigo. Archivo Español de Arte 190-191: 199-215.

(15) Azofra, E. (2006). Un hito en la arquitectura española de finales del siglo XVI: la Capilla Cerralbo de Ciudad Rodrigo. Ciudad Rodrigo. Parroquia de El Sagrario de la Catedral.

(16) Bustamante García, A. (1983). La arquitectura clasicista del foco vallisoletano (15611640). Valladolid. Institución cultural Simancas.

(17) Marías, F. (1989). El largo siglo XVI. Los usos artísticos del Renacimiento español. Madrid. Taurus.

(18) Arnuncio Pastor, J. C. (1986). 51 dibujos para una exposición. En Herrera y el clasicismo. Ensayos, catálogo y dibujos en torno a la arquitectura en clave clasicista, Valladolid. Junta de Castilla y León: 281-397.

(19) Goy Diz, A. (1993). Los trasmeranos en Galicia: la familia de los Arce. En Juan de Herrera y su influencia. Actas del Simposio - Camargo, 14/17 julio de 1992. Santander. Fundación Obra Pía Juan de Herrera y Universidad de Cantabria: 147-163.

(20) Ruiz Hernando, J. A. (2003). Las trazas de la catedral de Segovia. Segovia. Diputación Provincial de Segovia y Caja Segovia. 
(21) Pizzi Guevara, S. (2011). Las cúpulas renacentistas de la catedral de Segovia: historia, geometría, diseño y estabilidad. En Actas del Séptimo Congreso Nacional de Historia de la Construcción, Madrid. Instituto Juan de Herrera: 1119-1131.

(22) Alonso Rodríguez, M. A. con J. Calvo López y E. Rabasa Díaz (2009). Sobre la configuración constructiva de la cúpula del crucero de la Catedral de Segovia. En Actas del Sexto Congreso Nacional de Historia de la Construcción, Madrid. Instituto Juan de Herrera: 53-62. 